\title{
Challenges of reconstructing a large frontal defect following electrical burns in a resource limited environment: Our experience
}

\author{
Adeola Davis Sunday ${ }^{1 *}$, Okeke Uche Albert ${ }^{1}$, Agbara Rowland $^{2}$ and Onyebuchi Polycarp ${ }^{1}$ \\ ${ }^{1}$ Department of Oral and Maxillofacial Surgery, Ahmadu Bello University Teaching Hospital, Nigeria \\ ${ }^{2}$ Department of Oral and Maxillofacial Surgery, Jos University Teaching Hospital Jos, Nigeria
}

\begin{abstract}
Facial electrical burn injuries are rare and complex. They require initial primary management followed by multi-staged secondary reconstruction to obtain satisfactory functional and aesthetic results.

We present a 32years old male electrical technician with an indigenous company who sustained electrical burns to the maxillofacial region while fixing a faulty transformer. Initial resuscitation was done in a peripheral Hospital before referral to us. He had necrosis of the frontal and temporal soft and hard tissues bilaterally, loss of the upper eye lid bilaterally and loss of vision in the right eye. He had debridement of entire necrotic soft tissue and multi-staged saucerization and trephination of necrotic cranial bone was done over a period of 18 months to allow granulation tissue to form. Subsequently a split thickness skin graft was harvested from the right thigh and laid to cover the frontotemporal defect. The desire and determination of both the patient and surgical team to improve on appearance led to a fairly acceptable outcome notwithstanding the challenges of inadequate funds, poor facilities and equipment and limited experience in micro vascular free flaps.
\end{abstract}

\section{Introduction}

High-voltage electrical burns represent a challenging surgical entity. Compared to conventional burns, these injuries are characterized by an increased morbidity and worse potential for rehabilitation [1]. Electrical bums are infrequent when compared with flame and scald burns [2]. It accounts for 1500 deaths per year and more than 4000 cases reported to the emergency unit in the United States [3]. These injuries also account for $2 \%$ to $3 \%$ of all admissions to hospital burn centers, and that number is slowly increasing. ${ }^{4}$

\section{Case report}

A 32 years old male electrical technician with an indigenous company who sustained electrical burns to the face while on routine repair of a faulty transformer. Immediate resuscitation with intravenous fluid and antibiotics was done in a primary health centre close to the location of the accident. He presented to our clinic 10 days after the accident. At presentation he was stable, conscious, well oriented but in moderate pain. There was necrosis of soft tissues of the bridge of the nose, frontal, temporal regions and upper eye lids bilaterally. Ophthalmological examination revealed loss of vision in the right eye and exposure keratitis of the left eye. Soft tissue debridement was done under general anaesthesia after routine investigation which confirmed necrosis of frontal and temporal bones (Figures 1,2).

Saucerization and trephination of frontal and temporal bones was done under intravenous sedation using a drill and a blunt bur to remove necrotic bone to induce formation of granulation tissue (Figures 3,4). Subsequently a split thickness skin graft was harvested from the right thigh to cover the defect. The Ophthalmologist covered the left viable eye with saline soaked gauge after application of chloramphenicol ointment and patient was adviced to get sunglasses to protect the eye [4-6] (Figures 5,6).

\section{Discussion}

Electrical burns may be due to direct tissue contact or tissue reception of an electrical arc. ${ }^{5}$ The effect of the electrical current on tissues of an individual is dependent upon: (1) Voltage (2) amperage (3) type of current (4) resistance at the point of contacts (5) path of current through the body (6) duration of contact and (7) individual susceptibility [6]. Surgical management of this was multidisciplinary with both ophthalmology and neurosurgical inputs. Debridement
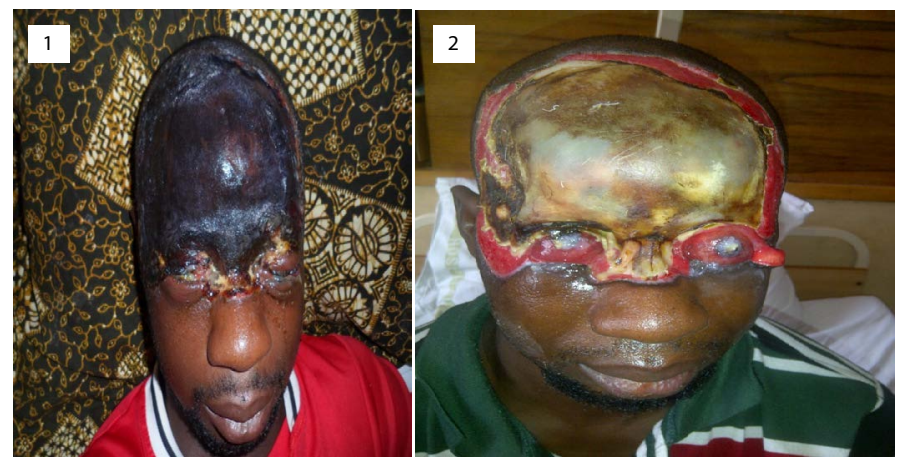

Figures 1,2. Necrosis of frontal and temporal bones

Correspondence to: Dr. Adeola Davis Sunday, BDS, FWACS, Reader/Consultant Oral and Maxillofacial Surgeon, Department of Oral and Maxillofacial Surgery, Ahmadu Bello University Teaching Hospital, Shika-Zaria, Kaduna State, Nigeria, Tel: +2348037189654, E-mail: adeolad@hotmail.com

key words: electrical burns, saucerization, trephination, micro vascular free flap Received: May 19, 2017; Accepted: June 12, 2017; Published: June 15, 2017 


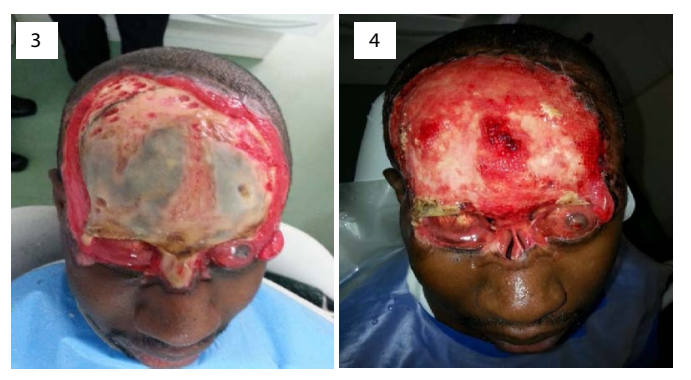

Figures 3,4. Saucerization and trephination of frontal and temporal bones

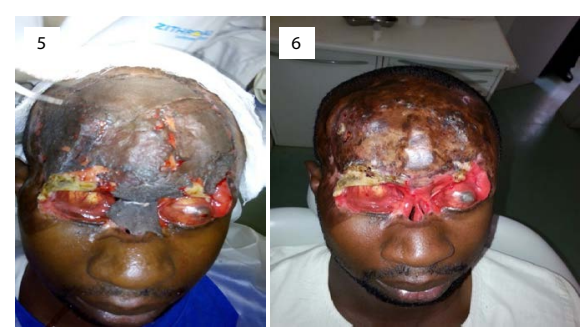

Figures 5,6. Split thickness skin graft followed by granulation tissue formation and skin grafting provided a fairly acceptable result.

In conclusion management of facial defects due to electrical burn in our environment is challenging due to inability to pay for procedures by patient, poor facilities and equipment and limited exposure in micro vascular free flap procedures.

\section{References}

1. Handschin AE, Jung FJ, Guggenheim M, Moser V, Wedler V, et al. (2007) Surgical treatment of high-voltage electrical injuries. Handchir Mikrochir Plast Chir 39: 345349. [Crossref]

2. Pitts W, Pickrell K, Quinn G, Massengill R (1969) Electrical burns of lips and mouth in infants and children. Plast Reconstr Surg 44: 471-479. [Crossref]

3. Zubair M, Besner GE (1997) Pediatric electrical burns: management strategies. Burns 23: 413-420. [Crossref]

4. Joffe MD FG, Ludwig S (2000) Burns. Textbook of Pediatric Emergency Medicine. (4 $4^{\text {th }}$ edn). Philadelphia: Lippincott Williams \& Wilkins: 1427-1434.

5. Sturmer FC (1961) Electrical Burns: A Case Report. Ann Surg 154: 120-124. [Crossref]

6. Pearl FL (1933) Electric Shock. Arch Surg 27.

Copyright: (C2017 Sunday AD. This is an open-access article distributed under the terms of the Creative Commons Attribution License, which permits unrestricted use, distribution, and reproduction in any medium, provided the original author and source are credited. 